\title{
Reciprocal Relationship between Lecturer Performance and Implementation UKI's Values at Universitas Kristen Indonesia
}

\author{
Dirk Roy Kolibu', Wellem Sairwona ${ }^{2}$ \\ 1,2Universitas Kristen Indonesia \\ Email: dirk.kolibu@uki.ac.id
}

\begin{abstract}
The implementation of the values of Universitas Kristen Indonesia (UKI) is important to be applied and implemented in the education process to develop the quality of the lecturer's character so that its implementation can be seen through the behaviour that is reflected in a person which is a combination of all good values, including behaviour that must look like: humility, sharing and caring, discipline, professional, responsibility, and integrity. The benchmark is the courage to change its performance to become a positive and constructive work culture. This study uses a quantitative research design with a casual and interactive approach. This study found that: there is a positive and significant relationship between lecturer performance and the implementation of UKI values. The correlation coefficient is 0.612 , determination is $37.4 \%, \mathrm{t}$-count $(5,068)>(2,000)$, and the regression equation $=$ $19.975+0.528 \mathrm{X}_{1}$. The reciprocal relationship between lecturer performance and the implementation of UKI values is significant or positive. The higher the level of implementation of the UKI values, the higher the lecturer's performance. On the other hand, the higher the performance of the lecturers, the more they support the implementation of the UKI values. The conclusion is that implementing UKI values in academic activities or academic support will develop character qualities or personal qualities, which tend to determine the quality of one's relationships with other people and their relationship with the environment in which they are located.
\end{abstract}

Keywords: Work Ethic, Lecturer Performance, Implementation of Values.

\section{A. INTRODUCTION}

Implementing the Universitas Kristen Indonesia (UKI) values, which is carried out with high integrity, is essential for lecturers and students to achieve academic performance. However, it is not uncommon for those who fail because they do not have a predetermined pattern or rules as a logical reference in action. UKI has established working rules that lecturers and students must implement as learning objectives. It has been stated in the UKI values, namely, humility, sharing and caring, discipline, professionalism, responsibility, and integrity.

Various efforts have been made to produce quality education in UKI and its outputs, such as organizing a persuasive learning process, mentoring, mentoring, and counselling to provide their conative and cognitive understanding and awareness. That is, the implementation of education in Christian universities aims to build and shape the values of academic life among students, educators (lecturers), and education staff (staff and employees). It is an indicator that must be implemented to get recognition from the outside world but must become a scientific and spiritual character of the UKI extended family. UKI itself is a Christian college 
with links to the Communion of Churches in Indonesia (PGI), formerly known as the Council of Churches in Indonesia (DGI) [1]. UKI is the oldest Christian university in Indonesia that has pledged that Jesus Christ is Lord and Savior as the centre of the movement to serve God through education. The word "Christian" in the name of the UKI university is a "mental, moral and spiritual awakening movement ready to fight" in implementing his abilities as a Christian scientist in Indonesia.

The implementation of UKI values has a religious character because UKI is a Christian higher education institution with the motto "Serving, Not Being Served" (Matthew 20:28). The slogan must be seen in the behaviour of a person who is a combination of all UKI values. The benchmark is the courage to change its performance to become a positive and constructive work culture. Therefore, UKI seeks to develop an academic quality assurance unit to have quality graduates so that stakeholders can utilize it. Academic quality assurance is closely related to the main actors in the educational process, namely lecturers. A lecturer is an educator who has academic qualifications, competencies, educator certificates, is physically and mentally healthy, and meets other qualifications required by the higher education unit where he is assigned and can achieve national education goals, according to Law Number 20 of 2003 concerning the National Education System [2]. It is confirmed in Law Number 12 of 2012 concerning Teachers and Lecturers. That is, lecturers are professional educators and scientists who have the main task of transforming, developing, and disseminating science, technology, and art through education, research, and community service. Its significance can be seen from the quality of lecturers in carrying out the teaching and learning process with students. That is, the activeness of the lecturer during the learning process is the key to success. Likewise, student activity during the educational process is essential.

Therefore, it is necessary to assess the work of lecturers to measure the extent of the performance of lecturers in the learning process. Lecturer work assessment is an evaluation in the organization to improve the quality of the performance, which is applicable. Lecturer performance appraisal is also an evaluation process to assess lecturers' performance or evaluate the work of lecturers [3; 4]. Forms of work can be done by collecting data in the form of information, such as how lecturers carry out the tri dharma process of higher education, namely education, research, and community service. So what is meant by evaluating the performance of lecturers? The first is to measure whether the lecturer has implemented the tri dharma of lecturers' colleges periodically and consistently? The second is evaluating whether UKI values are integrated into the lecturers' learning process in the classroom. The third is assessing lecturers' performance; can they be accounted for a clean toy? All of this is an intrinsic analytical process in implementing the tri dharma of higher education on campus. Thus, the implementation of the UKI values will be integrated into all accelerations of the performance of the Tridharma. The goal is that a lecturer is not only high in knowledge but also has spirituality, good character (good attitudes), good temperament (perfect temperament), and noble habits (supreme habitual). That is a lecturer with integrity. 


\section{B. LITERATURE REVIEW}

The implementation of UKI values as UKI work culture is based on the UKI Statute and is described more concretely in the 2015-2019 UKI RENSTRA. The description of the values and the biblical basis is as follows: a) Application of humble work culture (humility) based on Philippians 2:3b is expected to create a sense of security (comfort), with attributes: friendliness, kindness, smile, patience, helpful, communicative, understanding, respectful, serving with heart and reaching out. A humble attitude will give comfort to others and is reflected in behaviour that is friendly, kind, smiling, patient, ready to help, communicative, understanding, respectful, and serving with heart; $b$ ) The application of a sharing and caring work culture based on Hebrews 10:24 is expected to create a sense of empathy, with attributes: listening, empathic, understanding, gracious, giving time and attention, and informative. The attitude of sharing and caring can be felt by others in the form of empathy and is reflected in the behaviour of being willing to listen, respecting others, understanding, generous, helpful to give time and attention, and being ready to provide the necessary information (informative); c) The application of a disciplined work culture based on Ephesians 5:16 is expected to create consistent processes and results, with attributes: on time, compliance, by the rule, and constant. Discipline will build consistency, and it will be reflected in timely, obedience, and consistent work behaviour; d) The application of a professional work culture based on Matthew 25:21 is expected to create a sense of satisfaction (satisfaction), with attributes: quick response/on-time/prompt, accurate, satisfactory, collaborative, skilful/competent/knowledgeable, informative, best service, assurance, thoroughness, breakthrough, and continuous improvement. A professional attitude will give satisfaction to others and is reflected in behaviour that is fast and timely in responding, is accurate, can work together, is expert and competent, provides the best service, can be guaranteed (assurance), brings breakthroughs, and bring continuous improvement; e) The application of a responsible work culture based on Matthew 25:23 is expected to create trustworthiness, with the attributes: reliability, transparency, fairness, by the rule/compliance, calculated risk, and open to suggestions. A responsible attitude will build trust and is reflected in behaviour that is trustworthy, transparent, fair, obeys the rules (compliance), can consider risks, and is open to suggestions; and f) The application of work culture of integrity based on Proverbs 19:1 is expected to create happiness, with the attributes: honesty, sincerity, credibility, morality, characteristically, personality, wholeness, cohesiveness, totality, unity, spirituality, good attitudes, perfect temperament, and supreme habitual. This attitude of integrity will benefit all parties and is reflected in the accordance between attitudes and actions, words with actions, and consistent in acting continuously whatever the risks (constant and continuous) [5].

From the understanding described above about UKI's values as UKI's work ethic, it can be concluded that these values are based on the word of God, which all Christians believe. The six values must be carried out comprehensively and integratively to maintain a high work culture in higher education institutions to 
produce work productivity in the context of the tri dharma of higher education. Suppose the value of integrity becomes a culture that is practised at UKI. In that case, the application of this work culture will create happiness (happiness), namely the condition of mind and body, taste and reason, physical and spiritual, which is full of joy (joyful) and peaceful both from happy and sad situations, happy or demanding. In other words, the happiness referred to here is not just a feeling that can change but a permanent condition that requires determination to enjoy the fullness of life [6; 7]. Attributes that can be applied to integrity are honesty, sincerity, credibility, morality, characteristically, personality, wholeness, cohesiveness, undivided (completely), totality, and unity (unity of words with actions). Therefore, a UKI with integrity should have spirituality, good character (good attitudes), good temperament (perfect temperament), and noble habits (supreme habitual) in the practice of daily life.

Integrity is not just an attitude, nor is it just a concept or theory. Integrity is also not a mere practice of life. Integrity is a combination of the way of thinking (mindset), moral values, attitude, speech, behaviour, the approach of life (praxis) to the daily habits of a person [8]. A person's integrity will benefit the person himself and others associated with him. To that person, he will be himself and far from being pretentious or hypocritical. For others, they will feel safe, comfortable, and prosperous with that person. Behaviour reflected in a person with integrity is a combination of all the values of the UKI above, namely humility, sharing and caring, discipline, professionalism, responsibility, and integrity.

An advanced higher education institution always conducts performance appraisals of each component on the campus to measure the development or progress of the organization in achieving targets, both in quality and quantity [9; 10]. One crucial component is the lecturer. The method used to measure the lecturer's behaviour is assessing the lecturer's work performance in carrying out his duties and the extent to which his duties have been carried out productively, effectively, and efficiently. For this reason, a clear understanding is needed to evaluate the performance of lecturers objectively.

According to Government Regulation Number 37 of 2009, a professional educator and scientist are tasked with transforming, developing, and disseminating science, technology, and art through education, research, and community service. As a functional academic staff, lecturers are required to produce their work performance. That means there are criteria for measuring performance, work implementation, and the work of a lecturer, following what is expected by the institution. The results of the assessment will be input for the progress of the institution as said Blazey, the input obtained aims to (1) improve performance, capability, and scholarly output, (2) facilitate communication and exchange of information about best educational practices with various types of educational institutions, and (3) as a tool to understand and improve the performance of educational institutions as well as guidelines in strategic planning [11]. 
Many factors influence the success of lecturer performance. The influence comes from internal and external factors. These two factors will affect the work performance of lecturers, both in the dimensions of work quality, work quantity, engagement, planning skills, effort in work, and overall achievement. The dimensions of work performance are primarily determined by factors of expertise, interest, motivation, and work situation [12]. In other words, work performance is strongly influenced by internal factors, namely ability, and external factors, namely motivation. These factors are closely related to the characteristics or behaviour and his ability to produce a memorable performance. Internal factors, namely a lecturer who has high skills, will respond to his duties quickly.

In contrast, lecturers who have low abilities have no effort in reconstructing what he has to do in carrying out the tasks requested by the institution. External factors, namely the influence of the work environment where the lecturer is located, such as the behaviour, attitudes, and actions of co-workers, leaders, and organizational culture, will significantly impact the performance that he will produce. The impact of these two factors will also affect the achievement of organizational goals and the progress of higher education institutions.

A lecturer is an educator who must have academic qualifications, competencies, educator certificates, physically and mentally healthy, as mandated by law [13]. That is, the main task of lecturers is not only to transform their knowledge but also to develop and disseminate science, technology, and art through education, research, and community service. Law Number 14 of 2005, chapter 1, paragraph 10, explains the existence of a set of knowledge, skills, and behaviours that must be possessed, internalized, and mastered, of course, by teachers and lecturers in carrying out their professional duties [14]. In other words, a lecturer must have academic abilities and skills in teaching as regulated in the Regulation of the Minister of National Education of the Republic of Indonesia Number 16 of 2007, concerning Academic Qualification Standards and Teacher or Educator Competencies. There it is explained that a lecturer must have four types of competencies, namely pedagogic competence, personality competence, social competence, and professional competence [15]. What is meant, of course, is that competence is a unified whole regarding a person's self-potential description consisting of his knowledge, skills, and attitudes related to how a person carries out his profession, in the form of concrete actions and work results. Indicators modified through their thinking: quality of work, ability, initiative, communication, and punctuality [16].

Another factor that affects the performance of lecturers is the aspect of work motivation. Motivation is a set of encouragement, direction, and maintenance of behaviour towards a particular goal. The motivational process begins with a physical or psychological need that activates a behaviour or drives aimed at the target [17]. The key to the motivational process lies in the meaning of the relationship between markets, industries, and goals. Bolton expresses that motivation is a concept used to describe the factors within a person that stimulate, 
maintain and channel behaviour towards a goal [18]. In other words, motivation is behaviour aimed at the target. Thus, lecturers who have motivation have a strong desire to achieve their work goals or specific goals that the institution has set. Activities carried out with great effort and high fighting power in achieving organizational goals is greatly influenced by a lecturer's ability to meet his individual needs [19].

If the motivation of UKI lecturers is related to the motto "Serving Not Being Served," then all forms of lecturer work assignments must be seen as a form of a lecturer's service to God. The teacher's motivation is to do what God wants or judges good. Lecturers must come to the process of enlightenment to understand what God's purpose or call to him is. Lecturers can imitate the ministry motivation of the Apostle Paul in Philippians 3:12-14. Paul's personal experience with Christ when God arrested him has been a strong motivation in Paul. Religious motivation is the source of all existing motivation because it directs him to build consistent ethical behaviour. God-centred motivation believes that "only God, who lives and works in history, can initiate, shape and motivate the moral life of His people" [20; 21]. In other words, Paul was held captive by eternal love. Jesus Christ. Bob Gordon said the more our hearts are held captive by something, the more we will want it; the more we want something, the greater our commitment to it, and the greater our duty, the more motivated we will be to achieve that desire. Gordon states that "a captive heart will refuse to accept failure and never give up. Like the Apostle Paul who continued to advance towards the goal to get the prize" [22]. Andar Ismail explained that the main characteristics of a Christian person or institution are rules and motivation. His actions must refer to Jesus. Furthermore, Andar said, "all those actions become Christian if motivated to Jesus, who has behaved and acted similarly" [23].

Based on the explanation above, the motivation of a UKI lecturer in the teaching and learning process should be based on service motivation. Gage and Berliner have divided service motivation into two dimensions, namely intrinsic motivation and extrinsic motivation. Intrinsic motivation is service motivation which refers to self-esteem from within to carry out activities. The extrinsic motivation is the motivation influenced by the waiter's self-esteem with sources from outside himself. The two service motivations influence both the perception and the servant's nature, which is revealed in his actions or behaviour in his performance [24; 25].

The significance of work motivation and performance is seen in the work environment. The work environment is the condition around the lecturer during activities, either physical or non-physical, which can affect the lecturer's performance at work, either directly or indirectly. The physical work environment is a physical situation around the lecturer's workplace that can affect it directly or indirectly [26; 27]. For a lecturer, the significant influence of a non-conducive environment can reduce the performance and motivation of the lecturer. On the other hand, a good work environment will create optimal, healthy, safe, and comfortable working conditions. A conducive work environment could make sense of security and 
encourage lecturers to work optimally [28; 29]. That is, the emotional aspect dramatically affects the work process of lecturers and dramatically determines the effectiveness of one's performance optimally to achieve good performance. It can also help work relationships among fellow lecturers and relationships with subordinates, superiors, and the physical environment in which the lecturer is placed [30]. "The work environment is everything around the workers that can affect him in carrying out the tasks assigned" [31]. Environmental influences can have a high psychological impact on the physical and psychological conditions in achievement. Thus, universities' work environment is significant because a nonconducive work environment will reduce lecturer performance. On the other hand, a conducive work environment will improve the performance of a lecturer.

\section{METHOD}

The type of research used is causal associative through a quantitative approach. According to Sugiono, causal associative research aims to determine the reciprocal relationship between two or more variables. (Sugiyono, 2019:145) It means that this study explains the nature of the influence of the variables studied. The researcher uses the causal associative quantitative method because the data used to analyze the variables are interconnected and expressed through numbers or a numerical scale. Concerning the relationship between these variables, this study will also find patterns or paradigms in the UKI environment related to these variables. These independent variables may have a role in shaping the implementation of UKI values.

The research population is the entire research object. In addition, the population is defined as "all members of people or objects (larger group) that have been clearly defined," which is the target of generalization. The population of this study is related to the title of this study, UKI lecturers who are active in the learning process in the even semester, 2019/2020 academic year. The samples of this research were the Deans, Heads of Study Programs, and UKI lecturers who were taken as a whole; 45 lecturers from various educational strata and academic positions and Deans and Heads of Study Programs. The sampling technique used is simple random sampling because the sampling of population members is done randomly, without regard to the existing strata in the population. The researcher assumes that all UKI lecturer activists are homogeneous because they have effectively carried out their respective study programs' teaching and learning processes. The taken sample has fulfilled homogeneity as a requirement for selecting the sampling technique. Data collection is done by making a questionnaire based on instruments that have been prepared to be distributed to lecturers and students as respondents. The method of data collection is in the form of filling out a questionnaire. To achieve smooth and accurate data collection, the authors collaborated with the Deans and Heads of Study Programs to distribute and collect questionnaires. The instrument used to collect lecturer performance, student academic performance, and UKI values implementation used a Likert model questionnaire. The Likert scale is a scale that 
can be used to measure attitudes, opinions, and perceptions of a person or group of people about a symptom or educational phenomenon.

\section{RESULT AND DISCUSSION}

The normality test results are intended to determine that the distribution of the study does not deviate significantly from the distribution of nominal data. One way to determine the value of normality is the Kolmogrof Smirnoff formula in this study.

Table 1: Normality Test Results

\begin{tabular}{lllllll}
\hline Tests of Normality & \multicolumn{7}{l}{} \\
\hline & \multicolumn{7}{l}{ Kolmogorov-Smirnov ${ }^{\mathrm{a}}$} & \multicolumn{3}{l}{ Shapiro-Wilk } & \\
& Statistic & $\mathrm{df}$ & $\mathrm{Sig}$. & Statistic & $\mathrm{df}$ & Sig. \\
Implementation of UKI Values & .087 & 45 & $.200^{*}$ & .964 & 45 & .171 \\
Lecturer Performance & .108 & 45 & $.200^{*}$ & .976 & 45 & .454 \\
\hline
\end{tabular}

*. It is a lower bound of the true significance.

a. Lilliefors Significance Correction

The test results above show the one-sample table Kolmogrof Smirnoff Text obtained the Asym Sig number. (2-tailed). The decision-making criteria are if significant $>0.05$, then the data is typically distributed. If the significance is $<0.05$, then the information is not normally distributed. From the results above, it can be concluded that the two variables' data on lecturer performance and the implementation of UKI values have a significance value of 2.00 because the significance is $>0.05$, so the data is declared to be normally distributed.

The results of this study found that there was a positive and significant relationship between lecturer performance and the implementation of UKI values. The correlation coefficient is 0.612 , determination is $37.4 \%$, $t$-count $(5,068)>(2,000)$, and the regression equation $=19.975+0.528 \mathrm{X}_{1}$. The reciprocal relationship between lecturer performance and the implementation of UKI values is significant or positive. The higher the level of implementation of the UKI values, the higher the lecturer's performance. On the other hand, the higher the lecturer's performance, the higher the UKI values are applied. It can be seen in the table below:

Table 2: Correlation Test Results

\begin{tabular}{llll}
\hline Correlations & & & \\
\hline & & $\begin{array}{l}\text { Implementation } \\
\text { of UKI Values }\end{array}$ & $\begin{array}{l}\text { Lecturer } \\
\text { Performance }\end{array}$ \\
\hline Implementation of UKI Values & Pearson Correlation & 1 & $.612^{* *}$ \\
& Sig. (2-tailed) & & .000 \\
& $\mathrm{~N}$ & 45 & 45 \\
Lecturer Performance & Pearson Correlation & $.612^{* *}$ & 1 \\
& Sig. (2-tailed) & .000 & \\
& $\mathrm{~N}$ & 45 & 45 \\
\hline
\end{tabular}

**. Correlation is significant at the 0.01 level (2-tailed). 
Table 3: Determination Test Results

\begin{tabular}{lllll}
\hline \multicolumn{5}{c}{ Model Summary } \\
\hline Model & $\mathrm{R}$ & R Square & Adjusted R Square & Std. Error of the Estimate \\
\hline 1 & $.612^{\mathrm{a}}$ & .374 & .359 & 5.596 \\
\hline a. Predictors: (Constant), Lecturer Performance
\end{tabular}

Table 4: T-Test Results

\begin{tabular}{|c|c|c|c|c|c|c|}
\hline \multicolumn{7}{|c|}{ Coefficients } \\
\hline \multirow[b]{2}{*}{ Model } & & \multicolumn{2}{|c|}{$\begin{array}{l}\text { Unstandardized } \\
\text { Coefficients }\end{array}$} & \multirow{2}{*}{$\begin{array}{c}\text { Standardized } \\
\text { Coefficients } \\
\text { Beta } \\
\end{array}$} & \multirow[b]{2}{*}{$\mathbf{t}$} & \multirow[b]{2}{*}{ Sig } \\
\hline & & B & Std. Error & & & \\
\hline 1 & (Constant) & 19.975 & 8.835 & & 2.261 & .029 \\
\hline & $\begin{array}{l}\text { Lecturer } \\
\text { Performance }\end{array}$ & .528 & .104 & .612 & 5.068 & .000 \\
\hline
\end{tabular}

a. Dependent Variable: Implementation of UKI Values

Based on the hypothesis test results above, it can be concluded that UKI lecturers have a good understanding of the implementation of UKI values applied and implemented in the education process so far. UKI's values are religious because UKI is a Christian higher education institution with the motto "Serving, Not Being Served" (Matthew 20:28). Its implementation can be seen through the behaviour reflected in a person, which is a combination of all good values, including behaviours that must appear such as humility, sharing and caring, discipline, professionalism, responsibility, and integrity. The benchmark is the courage to change its performance to become a positive and constructive work culture.

In theory, the results were obtained from testing variables related to social learning theory. This theory discusses how to analyze humans in the application of their life values. Testing these two variables shows a positive value, indicating that the respondents (UKI lecturers) already understand applying the UKI values. Positive values are expressed incompetence and work motivation, which is an impact that affects knowledge, actions, and the meaning of work for a lecturer. This condition is a good and valuable foundation for the future of UKI and for increasing lecturers' work motivation in the future. Thus, it can be concluded that the performance of lecturers in implementing the UKI values has created good work motivation and improved the performance of lecturers who have relational dimensions with others and are religious towards God.

\section{E. CONCLUSION}

Based on the discussion above, the researcher concludes that there is a significant relationship between lecturer performance and the implementation of UKI values at the Indonesian Christian University. Based on the hypothesis tested and proven true, the research demonstrates that the integrity value in the lecturers' performance has been appropriately implemented, following the vision and mission 
of UKI and the motto "Serving Not Being Served." Therefore, lecturers in implementing higher education tri dharma should deliver lecture material and be living examples with integrity and are willing to improve competence and work motivation according to UKI values from time to time. Although the hypothesis testing was accurate, the researchers acknowledge that the study still has significant flaws. As a result, the researcher suggests that more research be done on other variables that are related to and affect lecturer performance, such as institutional policy, work motivation, and lecturer competence, as well as the partial influence between the three problems so that the findings of this study can be helpful to other Christian universities.

\section{REFERENCES}

1. Number UU. of 2003 concerning the National Education System. Manajemen pendidikan: pedoman bagi kepala sekolah dan guru [Education management: guidelines for school principals and teachers]. Surakarta: University Muhammadiyah Press. 2004.

2. Nadeak, B., \& Naibaho, L. (2019). Managing Lecturers' Competence Development at Universitas Kristen Indonesia.

3. Sunarto, E., Naibaho, L., Sormin, E., \& Nadeak, B. (2021). The Integration of Lecturers' Professionalism and Intelligence with Environment Insight. Psychology and Education Journal, 58(2), 5981-5987.

4. Verhezen, P. (2008). The (ir) relevance of integrity in organizations. Public Integrity, 10(2), 133-149.

5. Veenhoven, R. (2013). Data-Book of Happiness: A Complementary Reference Work to 'Conditions of Happiness' by the Same Author. Springer Science \& Business Media.

6. Veenhoven, R. (2013). Conditions of happiness. Springer Science \& Business Media.

7. Valkenburg, G., Dix, G., Tijdink, J., \& de Rijcke, S. (2021). Expanding research integrity: A cultural-practice perspective. Science and engineering ethics, 27(1), 1-23.

8. Kulkarni, P. P. (2013). A literature review on training \& development and quality of work life. Researchers World, 4(2), 136.

9. Saroyan, A., \& Trigwell, K. (2015). Higher education teachers' professional learning: Process and outcome. Studies in educational evaluation, 46, 92-101.

10. Hou, A. Y. C., Morse, R., \& Chiang, C. L. (2012). An analysis of mobility in global rankings: making institutional strategic plans and positioning for building worldclass universities. Higher Education Research \& Development, 31(6), 841-857.

11. Kuranchie-Mensah, E. B., \& Amponsah-Tawiah, K. (2016). Employee motivation and work performance: A comparative study of mining companies in Ghana. Journal of Industrial Engineering and Management (JIEM), 9(2), 255-309.

12. Gee, N. C. (2018). The impact of lecturers' competencies on students' satisfaction. Journal of Arts and Social Sciences, 1(2), 74-86.

13. Rahim, R., \& Arfiah, A. (2020). Affecting Factors Performance of Lecturer Remains in the University of Muhammadiyah Buton. International Journal of Management Progress, 1(2), 41-49. 
14. Pahrudin, P., Martono, T., \& Murtini, W. (2016). The Effect of Pedagogic Competency, Personality, Professional and Social Competency Teacher to Study Achievement of Economic Lesson in State Senior High School of East Lombok District Academic Year 2015/2016. In Proceeding of the International Conference on Teacher Training and Education (Vol. 2, No. 1, pp. 332-345).

15. Pong, H. K. (2021). The cultivation of university students' spiritual wellbeing in holistic education: longitudinal mixed-methods study. International Journal of Children's Spirituality, 1-34.

16. Combs, G. M., Luthans, F., \& Griffith, J. (2008). Learning motivation and transfer of human capital development: Implications from psychological capital. In The peak performing organization (pp. 119-137). Routledge.

17. Williams, K. C., \& Williams, C. C. (2011). Five key ingredients for improving student motivation. Research in Higher Education Journal, 12, 1.

18. Burnes, B. (2004). Managing change: A strategic approach to organisational dynamics. Pearson Education.

19. Pryor, A. (2014). The God Who Lives: Investigating the Emergence of Life and the Doctrine of God. Wipf and Stock Publishers.

20. Coles, R. (2010). Lives of moral leadership: Men and women who have made a difference. Random House.

21. Engberg-Pedersen, T. (2010). Cosmology and Self in the Apostle Paul: The material spirit. Oxford University Press on Demand.

22. DeShon, R. P., \& Gillespie, J. Z. (2005). A motivated action theory account of goal orientation. Journal of Applied Psychology, 90(6), 1096.

23. Schwarz, G., Newman, A., Cooper, B., \& Eva, N. (2016). Servant leadership and follower job performance: The mediating effect of public service motivation. Public Administration, 94(4), 1025-1041.

24. Searle, T. P., \& Barbuto Jr, J. E. (2011). Servant leadership, hope, and organizational virtuousness: A framework exploring positive micro and macro behaviors and performance impact.Journal of Leadership $\mathcal{E}$ Organizational Studies, 18(1), 107-117.

25. Narasuci, W., Setiawan, M., \& Noermijati, N. (2018). Effect of work environment on lecturer performance mediated by work motivation and job satisfaction. Jurnal Aplikasi Manajemen, 16(4), 645-653.

26. Zhong, C. B., \& House, J. (2012). Hawthorne revisited: organizational implications of the physical work environment. Research in Organizational Behavior, 32, 3-22.

27. Nadeak, B., Naibaho, L., Sormin, E., \& Juwita, C. P. (2019). Healthy Work Culture Stimulate Performance. Indian Journal of Public Health Research $\mathcal{E}$ Development, 10(6), 1385-1389.

28. Pranitasari, D. (2019). The Effect of Managerial Effectiveness, Work Environment, and Team Work on Lecturer's Work Engagement (Q). International Journal of Innovative Technology and Exploring Engineering (IJITEE), 8(12), 2536-2542.

29. Nadeak, B., Iriani, U. E., Naibaho, L., Sormin, E., \& Juwita, C. P. (2019). Building 
Employees' Mental Health: The Correlation between Transactional Leadership and Training Program with Employees' Work Motivation at XWJ Factory. Indian Journal of Public Health Research \& Development, 10(6), 1373-1379.

30. Ashcraft, M. H., \& Kirk, E. P. (2001). The relationships among working memory, math anxiety, and performance. Journal of experimental psychology: General, 130(2), 224. 